Jurnal Keperawatan Silampari

Volume 5, Nomor 1, Desember 2021

e-ISSN: 2581-1975

p-ISSN: 2597-7482

DOI: https://doi.org/10.31539/jks.v5i1.2956

IDMEKpe

\title{
INHALASI AROMATERAPI LAVENDER TERHADAP KOMPLIKASI HEMODIALISIS PADA PASIEN GAGAL GINJAL KRONIS
}

\author{
Isna Amalia Mutiara Dewi ${ }^{1}$, Masfuri ${ }^{2}$ \\ Universitas Indonesia ${ }^{1,2}$ \\ isnaamalia.md@gmail.com ${ }^{1}$
}

\begin{abstract}
ABSTRAK
Penelitian ini bertujuan untuk mengetahui efektivitas inhalasi aromaterapi lavender terhadap komplikasi hemodialisis berupa kelelahan, kecemasan, penurunan kualitas tidur, nyeri penusukan AVF dan depresi. Metode yang digunakan dalam penelitian ini adalah pencarian literature secara sistematis dari beberapa database online. Hasil penelitian menunjukkan bahwa dari sepuluh artikel yang telah ditelaah, inhalasi aromaterapi lavender dapat mengurangi komplikasi hemodialisis yaitu kelelahan, kecemasan, penurunan kualitas tidur dan nyeri penusukan AVF, sedangkan untuk komplikasi hemodialisis berupa depresi, inhalasi aromaterapi lavender tidak menunjukkan hasil yang signifikan. Simpulan, secara keseluruhan inhalasi aromaterapi lavender efektif dalam mengatasi komplikasi hemodialisis kecuali untuk komplikasi depresi.
\end{abstract}

Kata Kunci: Aromaterapi, Inhalasi, Lavender, Minyak Esensial, Komplikasi Hemodialisis

\begin{abstract}
This study aims to determine the effectiveness of lavender aromatherapy inhalation against hemodialysis complications such as fatigue, anxiety, decreased sleep quality, AVF stabbing pain and depression. The method used in this research is a systematic literature search from several online databases. The results showed that from ten articles that had been reviewed, lavender aromatherapy inhalation could reduce hemodialysis complications, namely fatigue, anxiety, decreased sleep quality and AVF stabbing pain, while for hemodialysis complications such as depression, lavender aromatherapy inhalation did not show significant results. In conclusion, overall inhalation of lavender aromatherapy is effective in overcoming hemodialysis complications except for depression complications.
\end{abstract}

Keywords: Aromatherapy, Lavender, Inhalation, Essential oil, Hemodialysis Complication

\section{PENDAHULUAN}

Gagal ginjal kronis (GGK) adalah kondisi kronis yang mengakibatkan hilangnya fungsi ginjal yang membutuhkan manajemen medis dan keperawatan yang kompleks. GGK ini dialami oleh $10 \%$ dari populasi di seluruh dunia dan diperkirakan meningkat menjadi 30\% pada tahun 2050 (Mohamed \& Hafez, 2019; Wijaya \& Padila, 2019). Pada tahun 2018, Global Burden of Disease memperkirakan terjadi 5-10 juta kematian/tahun yang disebabkan oleh penyakit ginjal (Luyckx et al., 2018). Di Indonesia, sesuai dengan hasil Data Riset Kesehatan Dasar (Riskesdas) tahun 2018 mengungkapkan, prevalensi GGK sebesar 0,38\% atau sebanyak 713.783 jiwa, angka prevalensi ini meningkat jika dibandingkan dengan data Riskesdas tahun 2013 dengan prevalensi sebesar 0,2\% 
(Riskesdas, 2018). Menurut Indonesian Renal Registry (IRR) pada tahun 2018, sebagian dari penyandang GGK di Indonesia, telah jatuh ke dalam tahap akhir atau End Stage Renal Disease (ESRD) sehingga membutuhkan terapi pengganti ginjal, salah satunya dengan terapi dialysis (Wijaya \& Padila, 2019; Pernefri, 2018).

Hemodialisis adalah intervensi terapeutik yang paling umum digunakan untuk pasien dengan penyakit ginjal stadium akhir. Meskipun HD umumnya merupakan prosedur yang aman, komplikasi terkait terapi hemodialisis sering dijumpai. Komplikasi yang paling sering terkait termasuk hipotensi, kram otot, mual dan muntah, sakit kepala, pruritus, demam, menggigil, depresi, masalah tidur dan kelelahan, nyeri serta kecemasan (Raja \& Seyoum, 2020). Komplikasi hemodialisis yang diobati dengan menggunakan obat dikaitkan dengan efek samping dan dalam jangka panjang menyebabkan ketergantungan dan eksaserbasi komplikasi terkait penyakit, selain itu komplikasi hemodialisis juga dikaitkan dengan biaya tinggi terkait pengobatan yang harus di keluarkan setiap tahunnya. Mengubah pengobatan asli dengan Complementary and Alternative Medicine (CAM) telah mendapatkan popularitas selama satu dekade terakhir (Dehghan et al., 2020). Salah satu terapi CAM yaitu dengan menggunakan aromaterapi karena aromaterapi merupakan metode yang murah dan popular yang sering digunakan masyarakat.

Aromaterapi sebagai metode non farmakologis, telah dieksploitasi dalam banyak penelitian karena penggunaannya yang tidak berbahaya dan nyaman. Aromaterapi menggunakan minyak wangi yang diekstrak dari bunga dan tumbuhan untuk mengobati berbagai penyakit. Aromaterapi merupakan bagian dari pengobatan herbal dengan dasar tindakan yang sama dengan farmakologi modern dan dapat menghasilkan manfaat fisiologis atau psikologis. Salah satu minyak esensial yang sering digunakan yaitu minyak esensial lavender. Lavender merupakan salah satu herbal yang digunakan dalam aromaterapi. Lavender termasuk dalam keluarga lamiaceae dengan nama ilmiah lavandula angustifolia. Banyak penelitian telah membahas efek anti-nyeri, antianxiety dan antidepresan, dan peningkatan tidur. Beberapa peneliti percaya bahwa lavender memberikan efek psikologisnya melalui efek pada sistem limbik, terutama amigdala dan hippocampus (Jafari-Koulaee et al., 2020; Beyliklioğlu \& Arslan, 2019; Özkaraman et al., 2018).

Penggunaan minyak lavender secara inhalasi telah menarik perhatian banyak peneliti, ini dikarenakan teknik ini mudah dilakukan dan dilaporkan memiliki efek positif terhadap beberapa keluhan yang dirasakan pasien, khususnya pasien hemodialisis. Penelitian yang dilakukan oleh hemodialisis Özdemir \& Akyol (2021) menemukan bahwa inhalasi minyak lavender dapat mempengaruhi komplikasi hemodialisis berupa penurunan rasa nyeri penusukan AVF secara signifikan pada pasien. Hasil penelitian serupa terhadap komplikasi hemodialisis dilakukan oleh hemodialisis Varaei et al., (2021) penelitian ini menemukan bahwa menghirup aromaterapi lavender dapat menurunkan kelelahan pada pasien hemodialisis.

Penelitian ini merupakan penelitian systematic review pertama yang membahas secara khusus tentang efek aromaterapi lavender pada komplikasi hemodialisis, selain itu penelitian ini juga mengumpulkan artikel yang hanya membahas satu jenis aromaterapi dengan satu teknik khusus, yaitu pemberian aromaterapi lavender dengan teknik inhalasi sehingga kesimpulan yang didapatkan pada systematic review dapat dijadikan evidence based practice yang detail sehingga diharapkan akan lebih mudah diterapkan dalam intervensi keperawatan. 


\section{METODE PENELITIAN}

Pertanyaan klinis adalah bagaimana pengaruh pemberian inhalasi aromaterapi terhadap komplikasi yang dialami pasien yang menjalani terapi hemodialisis dengan menggunakan pendekatan PICO (Population, Intervention, Comparative, Outcome). Pencarian artikel dilakukan selama lima hari yaitu pada tanggal 05 Mei 2021- 10 Mei 2021. Adapun database online yang digunakan adalah CINAHL, PubMed, Scopus dan Science Direct. Kata kunci pencarian yang digunakan adalah hemodialysis AND lavender OR aromatherapy OR essential oil AND inhalation AND hemodialysis complication.

Filter pencarian yang digunakan sesuai dengan kriteria inklusi yaitu sampel adalah pasien Gagal Ginjal Kronik (GGK) dengan terapi Hemodialisis (HD) yang mengalami komplikasi terkait HD, pasien GGK yang telah menjalani HD selama minimal 3 bulan, menjalani HD regular 2-3x/minggu, usia > 18 tahun, artikel dalam bahasa Inggris dan bahasa Indonesia, jenis penelitian RCT atau quasi eksperimen, artikel yang terbit tahun 2016-2021, artikel penelitian full text. Artikel systematic review dikeluarkan dalam penelitian ini.

Didapatkan sebanyak 145 artikel pada tahap awal pencarian. Setelah dilakukan skrining dengan membaca seluruh artikel dan disesuaikan dengan tujuan penelitian, maka didapatkan 10 artikel yang masuk dalam systematic review. Analisis artikel menggunakan Critical Appraisal Skills Programme (CASP) Part of Oxford Centre khusus untuk desain penelitian randomized controlled trial. Hasil penelusuran artikel penelitian disajikan dalam Gambar 1.

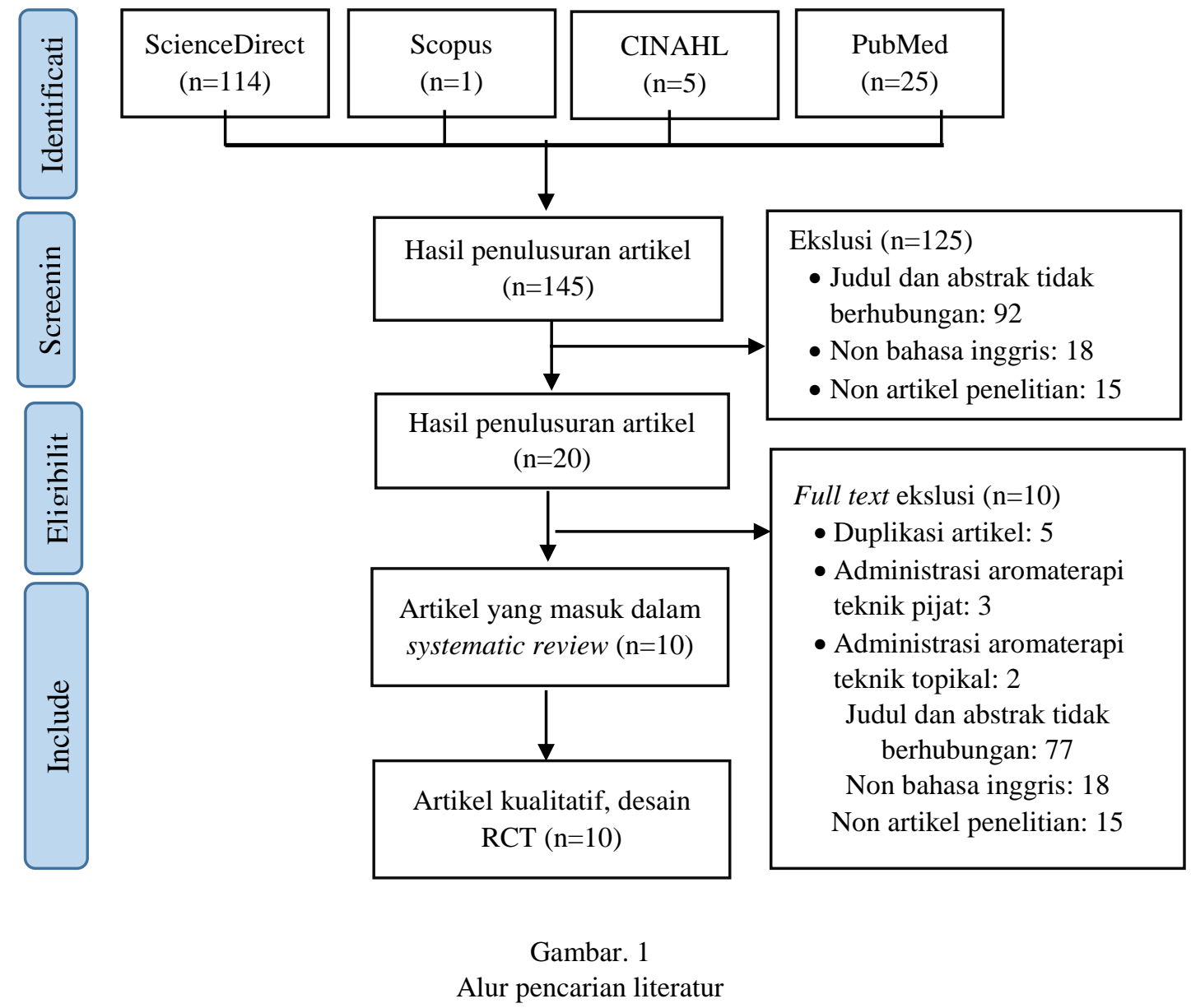




\section{HASIL PENELITIAN}

\section{Karakteristik Penelitian}

Penelitian dilakukan pada 553 pasien hemodialisis dengan usia rata-rata $47 \pm 14$ (rentang usia: 41,40-70,8 tahun). Sebagian besar peserta adalah perempuan $(\mathrm{n}=301 ; 54 \%)$. Dari 10 artikel yang disertakan, semuanya menggunakan desain RCT. Semua artikel diterbitkan dalam Inggris.

\section{Intervensi dan Protokol Administrasi Penelitian}

Semua artikel yang diteliti, yaitu sejumlah 10 artikel menggunakan metode inhalasi untuk aromaterapi lavender. Frekuensi penggunaan inhalasi aromaterapi lavender yang paling umum adalah adalah tiga kali seminggu $(n=7)$.

\section{Inhalasi Aromaterapi}

Dosis aromaterapi adalah dua, tiga dan lima tetes, tetapi dosis yang paling sering digunakan adalah dua tetes dan lima tetes. Frekuensi pengobatan adalah setiap hari sampai tiga hari seminggu, tetapi frekuensi yang paling umum adalah tiga hari seminggu. Konsentrasi minyak lavender yang digunakan adalah 2\%, 3\%, 5\%, 10\%, 20\%, 30\%, 40\%, $50 \%$, tetapi yang paling sering digunakan adalah minyak lavender dengan konsentrasi $2 \%$. Pada sebagian besar artikel, metode yang digunakan untuk aromaterapi inhalasi adalah dengan mengencerkan tetesan dan menuangkan larutan ke bola kapas/sapu tangan/kasa untuk ditempatkan di kerah pasien pada jarak yang sesuai $(15-30 \mathrm{~cm})$. Pasien kemudian diminta untuk bernapas normal selama beberapa menit dan bola kapas dibuang. Inhalasi aromaterapi lavender dilakukan sesuai dengan kebutuhan komplikasi yang diteliti baik pada siang hari maupun pada malam hari sebelum tidur. Durasi per sesi adalah 15 menit hingga lebih dari 10 jam (satu malam), tetapi durasi yang paling sering adalah 30 menit. Total durasi intervensi adalah dua minggu sampai dua bulan. Durasi total yang paling umum adalah empat minggu.

\section{Komplikasi dan Alat Pengukuran}

Komplikasi yang paling sering dipelajari adalah kecemasan $(n=6)$, kelelahan $(n=4)$, kualitas tidur yang buruk $(\mathrm{n}=2)$, nyeri pada tusukan Fistula Arteriovenosa (AVF) $(\mathrm{n}=2)$, depresi $(n=1)$. Instrumen yang paling sering digunakan adalah FSS $(n=4)$ dan BAI $(n=$ 2). Alat penilaian lainnya termasuk VAS, PSQI, STAI, HADS, szpillburger standard questionnaire, hamilton anxiety rating scale, SQS, NRS.

\section{Pengaruh Aromaterapi pada Komplikasi Hemodialisis Efek Psikologis}

Kecemasan: Enam penelitian mengevaluasi efek inhalasi aromaterapi lavender pada kecemasan pada pasien hemodialisis, dengan hasil inhalasi aromaterapi lavender memiliki efek positif pada pengurangan kecemasan dalam lima penelitian, dan tidak berpengaruh pada pengurangan kecemasan dalam satu penelitian lainnya.

Depresi: satu penelitian menyelidiki efek inhalasi aromaterapi lavender pada depresi pada pasien hemodialisis, dengan hasil inhalasi aromaterapi lavender tidak memiliki efek positif pada pengurangan depresi pada pasien hemodialisis. 


\section{Efek Fisik}

Kelelahan: Empat penelitian mengevaluasi efek inhalasi aromaterapi lavender pada kelelahan pada pasien hemodialisis, dengan hasil inhalasi aromaterapi lavender memiliki efek positif pada pengurangan kelelahan dalam empat penelitian yang dievaluasi.

Nyeri tusukan Fistula Arteriovenosa (AVF): dua penelitian mengevaluasi efek inhalasi aromaterapi lavender pada nyeri tusukan fistula arteriovenosa pada pasien hemodialisis, dengan hasil inhalasi aromaterapi lavender memiliki efek positif pada pengurangan nyeri tusukan fistula arteriovenosa dalam dua penelitian yang dievaluasi.

Kualitas tidur: dua penelitian membahas efek inhalasi aromaterapi lavender pada peningkatan kualitas tidur pada pasien hemodialisis, kemudian hasil penelitian menunjukkan efek positif inhalasi aromaterapi lavender pada peningkatan kualitas tidur pasien yang menjalani hemodialisis.

Tabel. 1

Hasil Pencarian Literatur

\begin{tabular}{|c|c|c|c|}
\hline $\begin{array}{c}\text { Pengarang, Judul, Jenis } \\
\text { Kiteratur }\end{array}$ & Tahun & Tujuan & Hasil Temuan \\
\hline $\begin{array}{l}\text { Sahin et al., } \\
\text { Effect of Lavender } \\
\text { Aromatherapy on } \\
\text { Arteriovenous Fistula } \\
\text { Puncture Pain and the } \\
\text { Level of State and Trait } \\
\text { Anxiety in } \\
\text { Hemodialysis Patients: } \\
\text { A Randomized } \\
\text { Controlled Trial, } \\
\text { Randomized Controlled } \\
\text { Trial }\end{array}$ & 2021 & $\begin{array}{l}\text { Untuk mengetahui } \\
\text { pengaruh aromaterapi } \\
\text { lavender terhadap nyeri } \\
\text { tusuk fistula } \\
\text { arteriovenosa dan } \\
\text { tingkat kecemasan status } \\
\text { dan sifat pada pasien } \\
\text { hemodialisis }\end{array}$ & $\begin{array}{l}\text { Penggunaan aromaterapi } \\
\text { lavander secara signifikan } \\
\text { menurunkan skor nyeri } \\
\text { akibat tusukan } \\
\text { arteriovenous fistula (AVF), } \\
\text { yaitu } 6,24 \pm 1,24 \text { pada sesi } \\
\text { pertama, menjadi } 3,56 \pm 1,28 \\
\text { pada sesi kedua pada pasien } \\
\text { kelompok intervensi } \\
\text { Skor rata-rata STAI } \\
\text { menurun pada pasien } \\
\text { kelompok intervensi setelah } \\
\text { aromaterapi adalah } \\
39,12 \pm 6,71 \text { dalam subskala } \\
\text { kecemasan keadaan dan } \\
30,04 \pm 1,39 \text { dalam subskala } \\
\text { kecemasan sifat. }\end{array}$ \\
\hline $\begin{array}{l}\text { Karadag et al., } \\
\text { The Effect of } \\
\text { Aromatherapy on } \\
\text { Fatigue and Anxiety in } \\
\text { Patients Undergoing } \\
\text { Hemodialysis } \\
\text { Treatment: A } \\
\text { Randomized Controlled } \\
\text { Study, } \\
\text { Randomized Controlled } \\
\text { Trial }\end{array}$ & 2019 & $\begin{array}{l}\text { Untuk mengetahui } \\
\text { pengaruh aromaterapi } \\
\text { terhadap kelelahan dan } \\
\text { kecemasan pada pasien } \\
\text { yang menjalani } \\
\text { perawatan hemodialisis }\end{array}$ & $\begin{array}{l}\text { Penerapan aromaterapi } \\
\text { dengan minyak lavender } \\
\text { untuk pasien yang } \\
\text { menjalani hemodialisis } \\
\text { berpengaruh pada } \\
\text { penurunan tingkat kelelahan } \\
\text { dan kecemasan. }\end{array}$ \\
\hline $\begin{array}{l}\text { Mohamed et al., } \\
\text { Effect of Aromatherapy } \\
\text { on Sleep Quality, } \\
\text { Fatigue and Anxiety } \\
\text { among Patients } \\
\text { Undergoing } \\
\text { Hemodialysis, } \\
\text { Randomized Controlled } \\
\text { Trial }\end{array}$ & 2019 & $\begin{array}{l}\text { Untuk mengetahui } \\
\text { pengaruh aromaterapi } \\
\text { terhadap kualitas tidur, } \\
\text { kelelahan dan } \\
\text { kecemasan pada pasien } \\
\text { yang menjalani } \\
\text { hemodialisis }\end{array}$ & $\begin{array}{l}\text { Inhalasi minyak lavender } \\
\text { dapat meningkatkan } \\
\text { kualitas tidur, } \\
\text { menghilangkan kelelahan } \\
\text { dan mengurangi kecemasan } \\
\text { pada di antara pasien yang } \\
\text { menjalani hemodialisis }\end{array}$ \\
\hline
\end{tabular}




\begin{tabular}{|c|c|}
\hline $\begin{array}{l}\text { Ahmady et al., } \\
\text { Comparing Effects Of } \\
\text { Aromatherapy With } \\
\text { Lavender Essential Oil } \\
\text { And Orange Essential } \\
\text { Oil On Fatigue Of } \\
\text { Hemodialysis Patients: } \\
\text { A Randomized Trial, } \\
\text { Randomized Controlled } \\
\text { Trial }\end{array}$ & 2019 \\
\hline
\end{tabular}

Bagheri-Nesami et al., Effect of Lavender

Aromatherapy on Well-

Being among

Hemodialysis Patients:

A Randomized Clinical

Trial,

Randomized Controlled

Trial

Inhalasi minyak lavender menurunkan tingkat keparahan kelelahan di antara pasien yang menjalani hemodialisis. Inhalasi aromaterapi lavender merupakan metode yang mudah dilakukan, terjangkau serta efektif dalam menurunkan tingkat kelelahan pasien

$\begin{array}{ll}2018 & \text { Untuk mengetahui } \\ & \text { pengaruh aromaterapi } \\ & \text { lavender pada } \\ & \text { kesejahteraan di antara } \\ & \text { pasien hemodialisis }\end{array}$

Minyak lavender dengan konsentrasi $40 \%$ dan 50\% memiliki 50\% efek positif terhadap kesejahteraan fisik dan psikis pada pasien hemodialisis, namun pada konsentrasi 10\%, 20\%, dan $30 \%$ tidak memiliki efek yang sebanding. Rendahnya konsentrasi minyak esensial lavender tidak berpengaruh pada peningkatan kesejahteraan pada pasien hemodialisis.

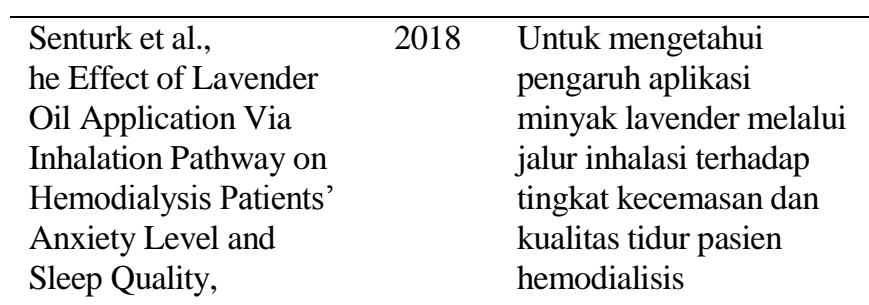

Randomized Controlled hemodialisis Inhalasi minyak lavender selama seminggu dapat mengurangi kecemasan yang dilihat dari penurunan skor kecemasan pada subskala psikologis dan somatik. Inhalasi minyak lavender juga dapat meningkatkan kualitas tidur dengan peningkatan durasi tidur dan peningkatan skor rata-rata tidur dengan VAS.

Bagheri-Nesami et al., The Effects Of Lavender Essential Oil Aromatherapy On

Anxiety And

Depression In

Haemodialysis Patients, Randomized Controlled Trial

\section{Untuk menguji efek} aromaterapi minyak esensial lavender pada kecemasan dan depresi pada pasien hemodialisis

Tidak terjadi perbedaan secara satistik pada kecemasan dan depresi setelah intervensi aromaterapi minyak lavender. Terjadi penurunan tingkat kecemasan dan depresi pada kelompok intervensi sebesar 6,5\%, begitupula pada kelompok kontrol sebesar $11 \%$.

\begin{tabular}{l}
\hline Aliasgharpour et al., \\
Effect Of Lavender \\
Aromatherapy On The \\
Pain Of Arteriovenous \\
Fistula Puncture In \\
Patients On \\
Hemodialysis, \\
Randomized Controlled \\
Trial
\end{tabular}

Inhalasi aromaterapi lavender efektif untuk mengurangi nyeri tusukan AVF pada pasien hemodialisis 


\begin{tabular}{|c|c|c|c|}
\hline $\begin{array}{l}\text { Bagheri-Nesami et al., } \\
\text { The Effects of } \\
\text { Aromatherapy with } \\
\text { Lavender Essential Oil } \\
\text { on Fatigue Levels in } \\
\text { Haemodialysis Patients: } \\
\text { A Randomized Clinical } \\
\text { Trial, } \\
\text { Randomized Controlled } \\
\text { Trial }\end{array}$ & 2016 & $\begin{array}{l}\text { Untuk mengetahui } \\
\text { khasiat minyak atsiri } \\
\text { lavender dalam } \\
\text { mengurangi kelelahan } \\
\text { pada pasien hemodialisis }\end{array}$ & $\begin{array}{l}\text { Minyak esensial lavender } \\
\text { pada konsentrasi } 5 \% \text { tidak } \\
\text { secara positif } \\
\text { mempengaruhi tingkat } \\
\text { kelelahan pada pasien } \\
\text { hemodialisis }\end{array}$ \\
\hline $\begin{array}{l}\text { Kiani et al., } \\
\text { The Effect Of Inhaling } \\
\text { Lavender On } \\
\text { Hemodialysis Patient's } \\
\text { Anxiety } \\
\text { Randomized Controlled } \\
\text { Trial }\end{array}$ & 2016 & $\begin{array}{l}\text { Untuk mengetahui } \\
\text { pengaruh menghirup } \\
\text { lavender pada } \\
\text { kecemasan pasien } \\
\text { hemodialisis }\end{array}$ & $\begin{array}{l}\text { Aromaterapi dengan } \\
\text { esensial lavender dapat } \\
\text { efektif mengurangi } \\
\text { kecemasan hemodialisis. }\end{array}$ \\
\hline
\end{tabular}

Minyak esensial telah digunakan selama hampir 6.000 tahun untuk meningkatkan kesehatan fisik dan psikologis sehingga pasien sudah tidak asing dengan metode pengobatan ini. Saat ini terjadi peningkatan kebutuhan dan tujuan dalam menghindari perawatan yang menggunakan bahan kimia. Aromaterapi lavender/ minyak esensial lavender merupakan pemilihan pengobatan dengan zat alami untuk meningkatkan status emosional, kualitas tidur, mengurangi tingkat kelelahan, kecemasan dan nyeri. Aromaterapi lavender memiliki efek sedatif dan meningkatkan kesejahteraan fisik dan psikologis.

Aromaterapi lavender sebagai pengobatan non-farmakologis disukai sehubungan dengan tingginya prevalensi komplikasi hemodialisis. Perawat memiliki peran penting dalam memeriksa dan mengamati perilaku verbal dan non-verbal pasien dalam rangka meminimalkan komplikasi setelah dan sebelum hemodialisis. Perawat hemodialisis, sebagai profesional perawatan kesehatan yang selalu berhubungan dengan pasien, dapat menggabungkan praktik berbasis bukti seperti aromaterapi dalam manajemen perawatan komplikasi hemodialisis pada pasien. Penggunaan minyak lavender merupakan intervensi mandiri keperawatan yang tidak memiliki efek samping, mudah dilakukan untuk digunakan, non invasif, dan hemat biaya, serta dapat diterapkan pada pasien yang menjalani hemodialisis untuk memastikan pengendalian komplikasi hemodialisis pada pasien. Banyak sekali masalah kompleks biopsikososial pasien menjalani hemodialisis menyebabkan mereka mengalami komplikasi hemodialisis.

\section{PEMBAHASAN}

Pengkajian literatur secara sistematis ini dilakukan untuk mengetahui efektivitas aromaterapi terhadap komplikasi hemodialisis. Proses awalnya dimulai dari mencari artikel terkait di berbagai macam database pada tanggal 05 Mei 2021 - 10 Mei 2021. Ditemukan 10 studi relevan yang yang terkait, dengan penelitiannya dilakukan pada 553 pasien hemodialisis. Peneliti sengaja meneliti tentang efek inhalasi aromaterapi lavender dengan tujuan agar hasil dari pengkajian literatur secara sistematis ini lebih detail dan fokus. Hal ini dilakukan, mengingat terdapat berbagai macam aromaterapi lain selain lavender seperti: peppermint, sweet orange, rose dll.

Lavender adalah tanaman dari keluarga lamiaceae, dan banyak spesies dengan karakteristik kimia yang berbeda, termasuk lavandula angustifolia (juga disebut L. vera atau L. officinalis), L. stoechas, L. latifolia, dan Lavandula $x$ intermedia (persilangan 
antara L. latifolia dan L. angustifolia). Meskipun berbeda dari sudut pandang botani, yang disebutkan di atas spesies lavender memiliki kandungan dan sifat kimia utama yang serupa (Mohamed \& Hafez, 2019). Spesies lavender yang paling umum digunakan adalah $L$. angustifolia, spesies ini memiliki dua kandungan utama yaitu linalyl acetate dan linalool yang bertanggung jawab untuk efek farmakologis lavender (Donelli et al., 2019).

Linalyl acetate telah dilaporkan memiliki sifat antihipertensi dan juga telah terbukti menginduksi pemulihan gangguan kardiovaskular akut. Linalool telah dilaporkan memiliki berbagai bioaktivitas: anti-inflamasi, antikanker, antihiperlipidemia, antimikroba, antinoseptif, analgesik, neuroprotektif, dan sifat antidepresi. Linalool dilaporkan menurunkan tekanan darah dan diduga memiliki efek langsung pada otot polos pembuluh darah yang menyebabkan vasodilatasi pada arteri karotis. Selain itu, linalool telah terbukti menjadi antidepresan (Pereira et al., 2018).

Penggunaan minyak esensial lavender dengan cara inhalasi sangat mudah untuk dipraktikkan, dengan alasan ini, banyak peneliti yang menyelidiki efektifitas teknik ini dibandingkan dengan teknik lain seperti teknik secara topikal, melalui pijatan dls. Ketika minyak esensial yang digunakan dalam aromaterapi dihirup, beberapa molekul berbeda yang terkandung di dalam minyak ini dipindahkan ke sistem limbik otak melalui indra penghidu. Daerah amygdala dan hipokampus di sistem limbik adalah wilayah terpenting dalam mengolah aromanya. Amygdala mengelola respon emosi. Diazepam diketahui menurunkan rangsangan emosi eksternal dengan meningkatkan neuron penghambat yang mengandung asam $\gamma$-aminobutyric dalam amigdala. Lavender dianggap memiliki efek diazepam. Sistem limbik memberikan efek penenang dan efek relaksasi dengan berinteraksi dengan korteks serebral dan mempengaruhi detak jantung, darah tekanan, pernapasan, stres, dan tingkat hormonal (Karadag \& Baglama, 2019).

\section{Kelelahan}

Kelelahan adalah salah satu komplikasi yang tak terhindarkan dari hemodialisis, dan kebanyakan pasien hemodialisis menderita tingkat kelelahan yang tinggi. Penelitian yang dilakukan Bagheri-Nesami et al., (2018) mengungkapkan bahwa, sepertiga pasien hemodialisis melaporkan bahwa mereka merasa lebih buruk selama jam-jam pertama hemodialisis, dan seperempat dari mereka mengalami tingkat kelelahan yang tinggi setelah hemodialisis. Beberapa faktor yang berkontribusi terhadap kelelahan pada pasien hemodialisis, termasuk defisiensi nutrisi, perubahan fisiologis, kadar hemoglobin dan urea yang abnormal, gangguan tidur, depresi, dan faktor yang berhubungan dengan hemodialisis (larutan dialisis rendah natrium dan ultrafiltrasi tinggi, ketergantungan meningkat, terhubung ke mesin, dll). Selain itu, tingkat kelelahan pada pasien hemodialisis meningkat seiring bertambahnya usia dan riwayat dialisis, yang membatasi aktivitas hidup sehari-hari.

Kelelahan yang dialami pasien HD dapat mempengaruhi kualitas hidup. Pengurangan tingkat kelelahan pasien tentu dapat berkontribusi pada peningkatan kualitas hidupnya. Penerapan intervensi keperawatan berbasis bukti, yaitu inhalasi aromaterapi lavender terbukti dapat menurunkan tingkat kelelahan pasien HD. Dari empat artikel yang dievaluasi dalam penelitian ini dapat disimpulkan bahwa inhalasi aromaterapi lavender terbukti dapat mengurangi tingkat keparahan kelelahan yang dialami pasien hemodialisis. Efek inhalasi lavender terhadap tingkat kelelahan juga diujicobakan pada populasi pasien yang lain yaitu pada pasien prediabetis dan ibu dalam periode postpartum, hasil yang didapatkan dari uji coba ini sejalan dengan hasil yang ditemukan pada pasien hemodialisis yaitu inhalasi aromaterapi lavender dapat menurunkan tingkat kelelahan secara signifikan (Asazawa et al., 2018; Hur et al., 2019). 


\section{Kecemasan}

Kecemasan pada pasien hemodialisis adalah fenomena kompleks yang terkait dengan perilaku, psikologis, fisik, dan mental. Perubahan pernikahan keluarga dan kehidupan sosial; bergantung pada mesin dialisis, tim perawatan kesehatan, dan keluarga; disfungsi seksual; dan masalah ekonomi yang terjadi dengan terapi hemodialisis menyebabkan pasien menderita kecemasan. Kecemasan merupakan salah satu diantara komplikasi hemodialisis yang paling banyak dialami, yaitu sebesar 38\%. Gejala penyakit jangka panjang lainnya seperti kelelahan dan gangguan tidur juga merupakan faktor penting penting yang meningkatkan kecemasan. Adanya peningkatan kecemasan pada pasien yang menjalani hemodialisis dapat menyebabkan komplikasi seperti kram otot, gangguan jantung dan peningkatan angka kematian. Kecemasan juga bisa mempengaruhi perawatan diri dan pengobatan pasien (Karadag \& Baglama, 2019; Rezaei et al., 2018).

Inhalasi aromaterapi lavender terbukti dapat menurunkan tingkat kecemasan yang dialami pasien hemodialisis, ini terlihat dari enam artikel yang dievaluasi, lima artikel menunjukkan bahwa kecemasan pada pasien hemodialisa menurun setelah dilakukan inhalasi aromaterapi lavender. Hasil ini serupa dengan hasil penelitian lain pada kelompok pasien yang berbeda yaitu, inhalasi aromaterapi lavender dapat menurunkan kecemasan pada pasien yang mangalami kecemasan akibat nyeri luka bakar, pasien yang menjalani kemoterapi, pada pasien yang mengalami kecemasan preoperative serta pada ibu postpartum (Tsai et al., 2020; Jaruzel et al., 2019; Özkaraman et al., 2018). Satu artikel lainnya menunjukkan hasil bahwa inhalasi aromaterapi lavender tidak memiliki efek yang signifikan pada penurunan kecemasan pasien hemodialisis, hal ini dikarenakan banyak variabel lain dalam penelitian yang tidak dikontrol oleh peneliti dan menyebabkan bias penelitian, variabel itu adalah perkawinan, jenis kelamin, masalah keuangan dan kurangnya dukungan sosial.

\section{Kualitas Tidur}

Paparan stressor fisiologis dan psikologis yang dialami pasien hemodialisis dalam perjalanan penyakit dan pengobatannya, dapat menyebabkan gangguan tidur. Gangguan tidur telah dilaporkan oleh 50-80\% pasien hemodialisis. Gangguan tidur ini meningkatkan tingkat kecemasan dan menyebabkan pengaruh negatif pada kinerja, tingkat energi, aktivitas fisik, perawatan diri, tingkat efikasi diri, dan kualitas hidup (Şentürk \& Kartin, 2018).

Studi menunjukkan bahwa inhalasi aromaterapi lavender dapat meningkatkan kualitas tidur pada pasien hemodialisis. Efek inhalasi aromaterapi lavender juga diteliti untuk kualitas tidur pada orang tua hasilnya adalah, metode ini dapat meningkatkan kualitas tidur (Genç et al., 2020). Penelitian yang dilakukan Aalami et al., (2018); Samadi et al., (2021) meneliti efek inhalasi aromaterapi lavender pada pasien dengan sindrom korona akut serta meneliti tentang inhalasi aromaterapi lavender pada ibu hamil trismester ketika, kedua penelitian ini memiliki hasil yang sama yaitu inhalasi aromaterapi lavender dapat meningkatkan kualitas tidur Hal ini tentu sejalan dengan hasil penelitian yang dilakukan pada pasien hemodialisis yaitu, inhalasi aromaterapi lavender dapat meningkatkan kualitas tidur.

\section{Depresi}

Depresi adalah gangguan lain yang ditemukan pada pasien hemodialisis. Depresi dikaitkan dengan anhedonia, kesedihan, ketidakberdayaan, putus asa, rasa bersalah, gangguan tidur, nafsu makan menurun, dan gangguan hasrat seksual. Prevalensi pasien 
hemodialisis yang mengalami depresi masih tinggi tetapi hanya sebagian kecil yang gejala depresinya didiagnosis dan ditangani (Toding et al., 2021). Penelitian yang dilakukan (Collister et al., 2019) menemukan bahwa prevalensi depresi pada pasien hemodialisis dilaporkan sekitar 54\%. Depresi dapat mengurangi kualitas hidup terkait kesehatan dan meningkatkan risiko kematian pada pasien hemodialisis. Penggunaan antidepresan dapat menyebabkan sejumlah komplikasi pada pasien hemodialisis, seperti: obat-obatan ini dapat mengikat protein, tidak memiliki efek yang menguntungkan pada pembersihan ginjal dan dapat menghasilkan toksik metabolit. Selain itu, beberapa antidepresan, seperti trisiklik dapat menyebabkan komplikasi kardiovaskular, termasuk disritmia, pemanjangan interval QT dan hipotensi ortostatik (Collister et al., 2019; Semaan et al., 2018)

Gangguan depresi disebabkan oleh rangsangan stres yang diketahui memiliki hubungan erat dengan Nukleus Paraventrikular (PVN) di hipotalamus, yang memainkan peran penting dalam pengaturan respons perilaku terhadap stres melalui sumbu hipotalamus Hipofisis Adrenal (HPA). Sel-sel neuroendokrin yang mensintesis Corticotropin Releasing Factor (CRF), Oxytocin (OXT), Arginine Vasopressin (AVP), dan Brain Derived Neurotrophic Factor (BDNF) terletak di dalam PVN. Telah dilaporkan bahwa stresor mengaktifkan neuron OXT di PVN. Neuron OXT menghambat aktivasi neuron CRF, sehingga menyebabkan penekanan fungsi aksis HPA dan berpotensi bertindak sebagai antagonis stres. Penelitian telah melaporkan bahwa lavender memiliki efek pada neuron OXT pusat (Jobst et al., 2018; Matsushita et al., 2019; Tang et al., 2019).

Penelitian yang dilakukan Sánchez-Vidaña et al., (2019) menunjukkan bahwa menghirup minyak esensial lavender memperbaiki perilaku. Penelitian ini sejalan dengan penelitian lain yang dilakukan oleh Ogata et al., (2020) yang membuktikan bahwa menghirup aromaterapi lavender dapat mengurangi depresi. Jafari-Koulaee et al., (2020) dalam tinjauan sistematisnya juga menguraikan hasil yang sejalan yaitu, inhalasi aromaterapi lavender dapat mengurangi depresi sedang. Hasil ini bertentangan dengan hasil artikel yang dibahas dalam penelitian ini. Dalam evaluasi satu artikel yang didapatkan terkait dengan depresi pasien hemodialisis, menunjukkan bahwa inhalasi aromaterapi lavender tidak menunjukkan hasil yang signifikan terhadap depresi, hal ini dikarenakan banyak variabel lain dalam penelitian yang tidak dikontrol oleh peneliti dan menyebabkan bias penelitian, variabel itu adalah perkawinan, jenis kelamin, masalah keuangan dan kurangnya dukungan sosial. Selain itu perlu dilakukan penelitian lebih lanjut terhadap efek inhalasi aromaterapi lavender terhadap depresi pasien yang menjalani hemodialisis, dikarena saat ini peneliti hanya menemukan satu artikel saja terkait hal ini, jadi peneliti tidak dapat membandingkannya dengan artikel lain yang memiliki sampel dan metode yang sama.

\section{Nyeri Penusukan AVF}

Fistula Arteriovenosa (AVF) adalah akses vaskular jangka panjang untuk tindakan hemodialisis, yang merupakan metode akses vaskular terbaik hingga saat ini. Arteri radial dan vena cephalic di pergelangan tangan adalah pembuluh darah yang paling umum yang digunakan untuk fistula (fistula radiocephalic). Pemeliharaan akses vaskular merupakan tantangan utama pada hemodialisis kronis. Intervensi Fistula Arteriovenosa (AVF) berulang dalam pengobatan hemodialisis menginduksi nyeri pada pasien dan merupakan komplikasi yang sangat umum pada pasien yang menjalani hemodialisis, dengan pengulangan tindakan 2 sampai 3 kali dalam seminggu, sehingga pasien hemodialisis harus mengalami nyeri ini sekitar 320 kali/tahun. Keluhan nyeri terkait penusukan AVF dilaporkan oleh $60,9 \%$ pasien hemodialisis. Keluhan nyeri ini tentunya dapat meningkatkan 
kecemasan klien hingga dapat mempengaruhi kualitas hidup pasien (Şahin et al., 2021; Özdemir \& Akyol, 2021; Saputra et al., 2020).

Kontrol nyeri adalah salah satu tugas utama dalam keperawatan, oleh karena itu, perawat harus selalu mencari cara untuk mengontrol nyeri secara efektif. Nyeri dapat dikurangi dengan terapi farmakologis dan nonfarmakologis, atau dengan kombinasi keduanya. Berdasarkan penelitian lain, teknik yang berhasil digunakan untuk mengurangi rasa sakit setelah penyisipan jarum ke dalam fistula antara lain stimulasi saraf listrik transkutan, penggunaan krim prilocaine dan semprotan lidokainerapan dan cryotherapi. Namun, beberapa tindakan ini diduga memiliki efek negatif pada fungsi AVF dan tidak dapat digunakan untuk semua pasien. Minyak lavender memiliki efek analgesik, antimikroba, dan menenangkan. Minyak ini banyak digunakan pada pasien untuk mengurangi kecemasan dan stres yang berhubungan dengan nyeri yang disebabkan oleh analgesik (Özdemir \& Akyol, 2021; Sadigova et al., 2020; Arslan \& Akca, 2018).

Dalam dua artikel yang dievaluasi dalam penelitian ini, menunjukkan bahwa inhalasi aromaterapi lavender dapat menurunkan tingkat nyeri yang dirasakan pasien hemodialisis saat penusukan jarum pada AVF. Penelitian lain yang dilakukan pada sampel yang berbeda juga menunjukkan hasil yang sejalan dengan penelitian ini, yaitu inhalasi aromaterapi lavender dapat menurunkan/ mengurangi tingkat nyeri yang dirasakan pasien, penelitian tersebut dalam tinjauan sistematisnya bahwa aromaterapi lavender dapat meredakan nyeri pada luka episiotomi (Abedian et al., 2020). Serta penelitian oleh Kazeminia et al., (2020) dengan hasil bahwa aromaterapi lavender dapat digunakan dalam mengurangi nyeri persalinan.

\section{SIMPULAN}

Inhalasi aromaterapi lavender afektif dalam mengatasi komplikasi hemodialisis yaitu kelelahan, kecemasan, nyeri penusukan AVF serta penurunan kualitas tidur. Sedangkan efektifitas inhalasi aromaterapi lavender untuk komplikasi hemodialisis berupa depresi perlu dilakukan penelitian lebih lanjut dikarenakan artikel yang didapatkan hanya satu artikel dengan hasil bahwa inhalasi aromaterapi lavender tidak berpengaruh secara signifikan terhadap penurunan depresi pasien hemodialisis.

Tim perawatan dialisis dapat menggunakan metode inhalasi aromaterapi lavender sebagai terapi pelengkap untuk mengurangi beberapa komplikasi hemodialisis sekaligus dan dapat meningkatkan kualitas hidup pasien hemodialisis.

\section{SARAN}

Banyak sekali masalah kompleks biopsikososial pasien menjalani hemodialisis menyebabkan mereka mengalami berbagai komplikasi seperti kelelahan, kecemasan, depresi, nyeri serta penurunan kualitas hidup mereka. Perawat hemodialisis harus secara rutin mengevaluasi komplikasi terkait dengan terapi hemodialisis yang diterima pasien. Perawat hemodialisis, sebagai professional perawatan kesehatan yang selalu berhubungan dengan pasien, dapat menggabungkan praktik berbasis bukti seperti aromaterapi dalam manajemen perawatan gejala komplikasi pasien. Disarankan untuk melakukan studi lebih lanjut untuk menilai perbedaan konsentrasi minyak esensial lavender untuk memvalidasi konsentrasi ideal untuk peningkatan kesejahteraan kesehatan di antara pasien hemodialisis. 


\section{DAFTAR PUSTAKA}

Aalami, H., Moghadam, H. M., \& Moghaddam, M. B. (2018). Effect of Hybrid Aromatherapy on Sleep Quality of Patients with Acute Coronary Syndrome Admitted to Cardiac Care Unit. World Family Medicine Journal/Middle East Journal of Family Medicine, 16(1), 268-275. https://doi.org/10.5742/mewfm.2018.93231

Abedian, S., Abedi, P., Jahanfar, S., Iravani, M., \& Zahedian, M. (2020). The Effect of Lavender on Pain and Healing of Episiotomy: A Systematic Review. Complementary Therapies in Medicine, 53(March). https://doi.org/10.1016/j.ctim.2020.102510

Ahmady, S., Rezaei, M., \& Khatony, A. (2019). Comparing Effects Of Aromatherapy With Lavender Essential Oil And Orange Essential Oil On Fatigue Of Hemodialysis Patients: A Randomized Trial. Complementary Therapies in Clinical Practice, 36, 64-68. https://doi.org/10.1016/j.ctcp.2019.05.005

Aliasgharpour, M., Abbaszadeh, R., Mohammadi, N., \& Kazemnejad, A. (2016). Effect of Lavender Aromatherapy on the Pain of Arteriovenous Fistula Puncture in Patients on Hemodialysis. Nursing Practice Today, 3(1), 26-30. https://npt.tums.ac.ir/index.php/npt/article/view/125

Arslan, D. E., \& Akca, N. K. (2018). Pain Following Needle Insertion into a Hemodialysis Fistula and Influencing Factors. International Journal of Caring Sciences, 11(3), 1662-1670. http://search.ebscohost.com/login.aspx?direct=true\&db=rzh\&AN

Asazawa, K., Kato, Y., Koinuma, R., Takemoto, N., \& Tsutsui, S. (2018). Effectiveness of Aromatherapy Treatment in Alleviating Fatigue and Promoting Relaxation of Mothers during the Early Postpartum Period. Open Journal of Nursing, 08(03), 196209. https://doi.org/10.4236/ojn.2018.83017

Bagheri-Nesami, M., Shorofi, S. A., Nikkhah, A., Moghaddam, H. R., \& Mahdavi, A. (2018). Effect of Lavender Aromatherapy on Well-Being among Hemodialysis Patients: A Randomized Clinical Trial. Pharmaceutical and Biomedical Research, 4(2), 0-4. https://doi.org/10.18502/pbr.v4i2.215

Bagheri-Nesami, M., Shorofi, S. A., Nikkhah, A., \& Espahbodi, F. (2017). The Effects of Lavender Essential Oil Aromatherapy on Anxiety And Depression in Haemodialysis Patients. Pharmaceutical and Biomedical Research, 3(1), 8-13. DOI:10.18869/acadpub.pbr.3.1.8

Bagheri-Nesami, M., Shorofi, S. A., Nikkhah, A., Espahbodi, F., \& Koolaee, F. S. G. (2016). The Effects of Aromatherapy with Lavender Essential Oil on Fatigue Levels in Haemodialysis Patients: A Randomized Clinical Trial. Complementary Therapies in Clinical Practice, 22, 33-37. https://doi.org/10.1016/j.ctcp.2015.12.002

Beyliklioğlu, A., \& Arslan, S. (2019). Effect of Lavender Oil on the Anxiety of Patients Before Breast Surgery. Journal of Perianesthesia Nursing, 34(3), 587-593. https://doi.org/10.1016/j.jopan.2018.10.002

Collister, D., Rodrigues, J. C., Mazzetti, A., Salisbury, K., Morosin, L., Rabbat, C., Brimble, K. S., \& Walsh, M. (2019). Single Questions for the Screening of Anxiety and Depression in Hemodialysis. Canadian Journal of Kidney Health and Disease, 6. https://doi.org/10.1177/2054358118825441

Dehghan, M., Namjoo, Z., Bahrami, A., Tajedini, H., Shamsaddini-lori, Z., Zarei, A., Dehghani, M., Ranjbar, M. S., \& Rafiee, S. N. F. (2020). The Use of Complementary and Alternative Medicines, and Quality of Life in Patients Under Hemodialysis: A Survey in Southeast Iran. Complementary Therapies in Medicine, 51(May). https://doi.org/10.1016/j.ctim.2020.102431 
Donelli, D., Antonelli, M., Bellinazzi, C., Gensini, G. F., \& Firenzuoli, F. (2019). Effects of Lavender on Anxiety: A Systematic Review and Meta-Analysis. Phytomedicine, 65(July), 153099. https://doi.org/10.1016/j.phymed.2019.153099

Genç, F., Karadağ, S., Kiliç Akça, N., Tan, M., \& Cerit, D. (2020). The Effect of Aromatherapy on Sleep Quality and Fatigue Level of the Elderly: A Randomized Controlled Study. Holistic Nursing Practice, 34(3), 155-162. https://doi.org/10.1097/HNP.0000000000000385

Hur, M. H., Hong, J. H., \& Yeo, S. H. (2019). Effects of Aromatherapy on Stress, Fructosamine, Fatigue, and Sleep Quality in Prediabetic Middle-Aged Women: A Randomised Controlled Trial. European Journal of Integrative Medicine, 31, 100978. https://doi.org/10.1016/j.eujim.2019.100978

Jafari-Koulaee, A., Elyasi, F., Taraghi, Z., Ilali, E. S., \& Moosazadeh, M. (2020). A Systematic Review of the Effects of Aromatherapy with Lavender Essential Oil on Depression. Central Asian Journal of Global Health, 9(1), 1-14. https://doi.org/10.5195/cajgh.2020.442

Jaruzel, C. B., Gregoski, M., Mueller, M., Faircloth, A., \& Kelechi, T. (2019). Aromatherapy for Preoperative Anxiety: A Pilot Study. Journal of Perianesthesia Nursing, 34(2), 259-264. https://doi.org/10.1016/j.jopan.2018.05.007

Jobst, A., Sabaß, L., Hall, D., Brücklmeier, B., Buchheim, A., Hall, J., Sarubin, N., Zill, P., Falkai, P., Brakemeier, E. L., \& Padberg, F. (2018). Oxytocin Plasma Levels Predict the Outcome of Psychotherapy: A Pilot Study in Chronic Depression. Journal of Affective Disorders, 227, 206-213. https://doi.org/10.1016/j.jad.2017.10.037

Karadag, E., \& Baglama, S. (2019). The Effect of Aromatherapy on Fatigue and Anxiety in Patients Undergoing Hemodialysis Treatment: A Randomized Controlled Study. Holistic Nursing Practice, 33(4), 222-229. https://doi.org/10.1097/HNP.0000000000000334

Kazeminia, M., Abdi, A., Vaisi-Raygani, A., Jalali, R., Shohaimi, S., Daneshkhah, A., Salari, N., \& Mohammadi, M. (2020). The Effect of Lavender (Lavandula stoechas L.) on Reducing Labor Pain: A Systematic Review and Meta-Analysis. EvidenceBased Complementary and Alternative Medicine, 2020. https://doi.org/10.1155/2020/4384350

Kiani, F., Shahrakipour, M., \& Zadeh, M. A. H. (2016). The Effect of Inhaling Lavender on Hemodialysis Patient's Anxiety. https://www.researchgate.net/publication/306215643

Luyckx, V. A., Tonelli, M., \& Stanifer, J. W. (2018). The Global Burden of Kidney Disease and the Sustainable Development Goals. Bulletin of the World Health Organization, 96(6), 414-422C. https://doi.org/10.2471/BLT.17.206441

Matsushita, H., Latt, H. M., Koga, Y., Nishiki, T., \& Matsui, H. (2019). Oxytocin and Stress: Neural Mechanisms, Stress-Related Disorders, and Therapeutic Approaches. Neuroscience, 417, 1-10. https://doi.org/10.1016/j.neuroscience.2019.07.046

Mohamed, H. G., \& Hafez, M. K. (2019). Effect of Aromatherapy on Sleep Quality , Fatigue and Anxiety among Patients Undergoing Hemodialysis. IOSR Journal of Nursing and Health Science (IOSR-JNHS), 8(5), 17-25. https://doi.org/10.9790/1959-0805101725

Ogata, K., Ataka, K., Suzuki, H., Yagi, T., Okawa, A., Fukumoto, T., Zhang, B., Nakata, M., Yada, T., \& Asakawa, A. (2020). Lavender Oil Reduces Depressive Mood in Healthy Individuals and Enhances the Activity of Single Oxytocin Neurons of the Hypothalamus Isolated from Mice. Evidence-Based Complementary and Alternative Medicine, 2020. https://doi.org/10.1155/2020/5418586 
Özdemir, S. T., \& Akyol, A. (2021). Effect of Inhaler and Topical Lavender Oil on Pain Management of Arteriovenous Fistula Cannulation. Journal of Vascular Access, 8. https://doi.org/10.1177/11297298211031086

Özkaraman, A., Dügüm, Ö., Yılmaz, H. Ö., \& Yeşilbalkan, Ö. U. (2018). Aromatherapy: The Effect of Lavender on Anxiety and Sleep Quality in Patients Treated with Chemotherapy. Clinical Journal of Oncology Nursing, 22(2), 203-210. https://doi.org/10.1188/18.CJON.203-210

Pereira, I., Severino, P., Santos, A. C., Silva, A. M., \& Souto, E. B. (2018). Linalool Bioactive Properties and Potential Applicability in Drug Delivery Systems. Colloids and Surfaces B: Biointerfaces, 171, 566-578. https://doi.org/10.1016/j.colsurfb.2018.08.001

Pernefri. (2018). 11th Report Of Indonesian Renal Registry 2018. Irr, 1-46. https://www.indonesianrenalregistry.org/data/IRR 2018.pdf

Raja, S. M., \& Seyoum, Y. (2020). Intradialytic Complications among Patients on TwiceWeekly Maintenance Hemodialysis: An Experience from a Hemodialysis Center in Eritrea. BMC Nephrology, 21(1), 1-6. https://doi.org/10.1186/s12882-020-01806-9

Rezaei, Z., Jalali, A., Jalali, R., \& Khaledi-Paveh, B. (2018). Psychological Problems as the Major Cause of Fatigue in Clients Undergoing Hemodialysis: A Qualitative Study. International Journal of Nursing Sciences, 5(3), 262-267. https://doi.org/10.1016/j.jijnss.2018.07.001

Riskesdas. (2018). Laporan Riskesdas 2018 Kementrian Kesehatan Republik Indonesia. In Laporan Nasional Riskesdas 2018, 53(9), 154-165. http://www.yankes.kemkes.go.id/assets/downloads/PMK No. 57 Tahun 2013.pdf

Sadigova, E., Yalcin, A., \& Ozkurt, S. (2020). Pain Assessment in Hemodialysis Patients. Cureus, 12(2), 1-10. https://doi.org/10.7759/cureus.6903

Şahin, S., Tokgöz, B., \& Demir, G. (2021). Effect of Lavender Aromatherapy on Arteriovenous Fistula Puncture Pain and the Level of State and Trait Anxiety in Hemodialysis Patients: A Randomized Controlled Trial. Pain Management Nursing, 22(4), 509-515. https://doi.org/10.1016/j.pmn.2021.01.009

Samadi, Z., Jannati, Y., Hamidia, A., Mohammadpour, R. A., \& Hesamzadeh, A. (2021). The Effect of Aromatherapy with Lavender Essential Oil on Sleep Quality in Patients with Major Depression. Journal of Nursing and Midwifery Sciences, 8(2), 67-73. https://doi.org/10.4103/JNMS.JNMS_26_20

Sánchez-Vidaña, D. I., Po, K. K. T., Fung, T. K. H., Chow, J. K. W., Lau, W. K. W., So, P. K., Lau, B. W. M., \& Tsang, H. W. H. (2019). Lavender Essential Oil Ameliorates Depression-Like Behavior and Increases Neurogenesis and Dendritic Complexity in Rats. Neuroscience $\quad$ Letters, 701(February), 180-192. https://doi.org/10.1016/j.neulet.2019.02.042

Saputra, M., Harahap, I. A., \& Kasiman, S. (2020). Valsalva Maneuver to Decrease Pain Intensity During Arteriovenous Fistula Insertion in Hemodialysis Patients. Jurnal Keperawatan Indonesia, 23(2), 136-144. https://doi.org/10.7454/jki.v23i2.645

Semaan, V., Noureddine, S., \& Farhood, L. (2018). Prevalence of Depression and Anxiety in End-Stage Renal Disease: A Survey of Patients Undergoing Hemodialysis. Applied Nursing Research, 43(April 2018), 80-85. https://doi.org/10.1016/j.apnr.2018.07.009

Şentürk, A., \& Kartin, P. T. (2018). The Effect of Lavender Oil Application Via Inhalation Pathway on Hemodialysis Patients' Anxiety Level and Sleep Quality. Holistic Nursing Practice, 32(6), 324-335. https://doi.org/10.1097/HNP.0000000000000292 
Tang, A. L., Thomas, S. J., \& Larkin, T. (2019). Cortisol, Oxytocin, and Quality of Life in Major Depressive Disorder. Quality of Life Research, 28(11), 2919-2928. https://doi.org/10.1007/s11136-019-02236-3

Toding, D., Masfuri, M., \& Yona, S. (2021). Penerapan Terapi Psikologis dalam Menurunkan Depresi pada Pasien Hemodialisis: Literature Review. Jurnal Penelitian Kesehatan Suara Forikes, 12(3), 242-248. DOI: http://dx.doi.org/10.33846/sf12304

Tsai, S. S., Wang, H. H., \& Chou, F. H. (2020). The Effects of Aromatherapy on Postpartum Women: A Systematic Review. Journal of Nursing Research, 28(3), 111. https://doi.org/10.1097/jnr.0000000000000331

Varaei, S., Jalalian, Z., Yekani-Nejad, M. S., \& Shamsizadeh, M. (2021). Comparison the Effects of Inhalation and Massage Aromatherapy with Lavender and Sweet Orange on Fatigue in Hemodialysis Patients: A Randomized Clinical Trial. Journal of Complementary and Integrative Medicine, 18(1), 193-200. https://doi.org/10.1515/jcim-2018-0137

Wijaya, A., \& Padila, P. (2019). Hubungan Dukungan Keluarga, Tingkat Pendidikan dan Usia dengan Kepatuhan dalam Pembatasan Asupan Cairan pada Klien ESRD yang Menjalani Terapi Hemodialisa. Jurnal Keperawatan Silampari,3(1), 393-404. https://doi.org/https://doi.org/10.31539/jks.v3i1.883 